Wilfrid Laurier University

Scholars Commons @ Laurier

$10-2016$

\title{
Economic Well-Being and Social Justice through Pleasure Reading
}

Pauline Dewan

pdewan@wlu.ca

Follow this and additional works at: https://scholars.wlu.ca/lib_pub

Part of the Library and Information Science Commons

\section{Recommended Citation}

Dewan, Pauline, "Economic Well-Being and Social Justice through Pleasure Reading" (2016). Library Publications. 48.

https://scholars.wlu.ca/lib_pub/48

This Article is brought to you for free and open access by the Library at Scholars Commons @ Laurier. It has been accepted for inclusion in Library Publications by an authorized administrator of Scholars Commons @ Laurier. For more information, please contact scholarscommons@wlu.ca. 


\title{
Economic Well-Being and Social Justice through Pleasure Reading
}

Classification of article: Viewpoint

Keywords - Reading and society, Pleasure reading, Recreational reading, Literacy, Literacy and society, Literacy and social justice, Literacy and employment

\begin{abstract}
Purpose - Librarians planning for the future and unsure about the place of books in an age dominated by technology and media need evidence to make sound decisions. Library and information science researchers have studied the impact of pleasure reading on individuals but not on society. The purpose of this article is to raise awareness about the benefits of recreational reading for societies and to consider the implications of these findings for libraries.
\end{abstract}

Design/methodology/approach - Examining a wide range of studies by government bodies, intergovernmental agencies, and academics, this article addresses a gap in the library literature by critically evaluating the combined implications of sources not hitherto viewed together.

Findings - The more leisure books people read, the more literate they become, and the more prosperous and equitable the society they inhabit.

Practical implications - Librarians should create a more robust culture of reading and play a stronger advocacy role for books in libraries.

Originality/value -No one has yet examined government reports about literacy in relation to studies on the impact of pleasure reading. The implications of this combined research highlight the fact that pleasure reading benefits societies as well as individuals, a finding that has significant implications for the future direction of libraries. Decision makers who need a robust mandate for book-focused resources and services will find supportive statistical evidence in this article.

Since the 1990s, libraries have focussed on technology-based products and services. Although this paradigm shift has revolutionized libraries, updated their image, provided fresh opportunities for innovation, and attracted new customers, it has also moved books to the margins. Over the course of the last decades, circulation figures for books have steadily dropped in public, academic, and school libraries. In its most recent "Materials Breakout | Materials 
Survey," Library Journal reports that from 2011 to 2014 in the United States, circulation of print and e-books dropped from 68.3 to 63.1 percent of the total. Print books are the single biggest circulation failure, dropping an astonishing 9.1 percent in just three years. Although e-books are on the rise, they still account for only 5.4 percent of total circulation (Hoffert, 2015). Not surprisingly, libraries are under pressure to convert book-shelf space to media and technology uses. But has the pendulum swung too far away from books, our initial reason for being? Will libraries soon look like big-box bookstores, with books as peripheral to trendier merchandise? And are book-based services such as readers' advisory on the decline? In Library Journal's recent RA survey, almost half the respondents said readers' advisory services have not increased in importance in the last three years and will probably not do so in the next three (ThortonVerma and Schwartz, 2014). In our rush to embrace media and maker spaces, it is easy to dismiss the waning popularity of books as a reflection of our customer's changing preferences. But have books actually lost favour with the public? Although e-book sales may have reached their peak, The Financial Times claims that "the number of physical books sold in the U.S. rose 2.4 percent, ... the second successive annual rise" (Mance et al., 2015).

Certainly the variety of resources and services that libraries offer makes them more versatile and attractive to customers, a much-needed improvement that our customers value. But books need not be side-lined. The public views books as our brand (De Rosa et al., 2011, p. 38) so we should re-assess their place in our libraries. A number of studies have linked leisure reading with health, well-being, and success (for example, Gold, 2002; Gottschall, 2012; Oatley 2011; Ross, 2000). Scholars in library science, psychology, and English have studied the cognitive, psychological, social, and health benefits of reading for the individual. But a large body of research by government bodies, intergovernmental agencies, and academics about the 
relationship between reading, literacy, and society has gone largely unnoticed in the library community. These studies point to a remarkable conclusion: society functions better with readers. The statistical evidence in these reports can dramatically change the way librarians view reading. It can also provide them with the evidence they need to advocate for books and readers.

\section{Literacy as a Product of Frequent Reading}

We know that becoming literate is a by-product of reading. People who read frequently become more literate than those who do not. Becoming a skilled reader does not just happen by chance. Reading is an acquired skill, not an innate one; the more books we read, the better we become at it. As we become more proficient readers, new neural pathways develop in our brains, changing their existing circuitry (Wolf and Barzillai, 2009). Once our brains adapt, the mechanics of decoding words drop away and we become fluent readers. Catherine Ross observes that reading requires a long, intense apprenticeship: "People learn to read by doing lots and lots of reading" (2006, p. 45). Ross (2009) points to Malcolm Gladwell's claim that it takes 10,000 hours of practice at almost anything to become really proficient at it. Gladwell (2008) identifies pleasure as the secret ingredient that motivates people to put the thousands of necessary hours into an activity. When we read for enjoyment, we painlessly develop the skills necessary to become literate. Reading then becomes effortless and rewarding. Consequently, we turn to it as a favourite activity, which in turn further enhances our literacy skills. Far from the escapist activity that it has been depicted as, reading for pleasure is fundamental to the development of proficiency in literacy.

The importance of pleasure reading in literacy acquisition is evident in the OECD study, the International Student Assessment of Literacy. In all seventy surveyed countries, students who said they enjoyed reading the most performed significantly better on literacy tests than those who 
said they enjoyed it the least (OECD, 2010, p. 30). Another study by Victoria Rodrigo and colleagues compared two types of reading interventions for people with low literacy: direct literacy instruction and reading for pleasure. The respondents who spent time reading for pleasure increased their literacy skills far more than those who were taught formal literacy lessons (Rodrigo et al., 2014).

Governments around the world have a stake in the reading abilities of their citizens because the well-being and prosperity of their societies depends upon the skills of its members. Literacy is especially important because it underpins other proficiencies. So it is not surprising that government organizations have conducted a number of large-scale surveys on the effect of reading and literacy on society. Some of the most compelling evidence emerges from a series of large-scale, multi-country studies conducted over the last two decades by the Organization for Economic Co-operation and Development (OECD). These studies view literacy on a five-level continuum, rather than as an either/or construct. Level three is considered the minimum level needed to function in today's modern economy. In the OECD's twenty-country survey of adult skills, the Programme for the International Assessment of Adult Competencies (PIAAC), the average literacy score was 273 , just below level three (2013a, p. 70). Although the variation in scores between OECD countries is relatively small, the variation within counties is large. More than half the citizens in OECD countries, including the U.K., the U.S., and Canada, lack fundamental literacy skills, a survey result that is sobering.

\section{Literacy and Economic Success}

Research reveals a strong link between literacy and economic success, both for employees and societies. The PIAAC study concludes that per capita incomes are higher in countries with larger proportions of adults at the highest levels of literacy (2013a, p. 26). In fact, 
the median hourly wage of workers at levels four or five on the literacy scale is 61 percent higher than those scoring at or below level one (OECD, 2013a, p. 227). Even workers who tested at level three or above earn significantly more than individuals with lower skills (Statistics Canada and OECD, 2011, p. 79). The UK's National Literacy Trust Survey concludes that, after factoring in education, more literate employees still earn on average 12 percent more than less proficient workers (Morrisroe, 2014, p. 10). For the socio-economically disadvantaged, the relationship between literacy and salary often proves to be a vicious circle: low literacy negatively impacts earnings, which in turn affects literacy through lack of access to resources. Therefore raising literacy levels could be an important strategy in alleviating poverty in society (Morrisroe, 2014, p. 11). The Conference Board of Canada argues that literacy levels—not education-have the greatest impact on national prosperity (Campbell and Gagnon, 2006). Studies from the U.S.'s National Assessment of Adult Literacy, the UK's National Literacy Trust, Statistics Canada, and the OECD all conclude that higher literacy leads to greater overall success in the labour force. Specifically people with higher literacy skills are more likely to be employed and to be employed full-time (Kutner et al., 2007, p. vi; National Assessment of Adult Literacy, 2005, p. 16; OECD, 2013b, p. 6), have greater opportunities for advancement in the workplace (Davenport, 2005), are better able to assume different responsibilities if their jobs change (OECD, 2013b, p. 9), are more likely to work regularly when employed (OECD, 2000, p. 38), can better weather uncertainties in a rapidly changing labour market (OECD, 2013a, p. 23), and are more likely to be employed in skilled professions, managerial positions, and generally more rewarding jobs than their less literate counterparts (Kutner et al., p. vi; Morrisroe, 2014, p. 10; OECD, 2013a, pp. 27, 48; Statistics Canada and Employment and Social Development Canada, 2013, p. 37). 
Literacy skills are the bedrock of other essential labour-market skills. They are the foundation for higher-order cognitive skills and a prerequisite for specific domains of knowledge (Statistics Canada and Employment and Social Development Canada, 2013, p. 5). Poor literacy leads to low educational attainment which amasses and widens throughout the school years. It is also a roadblock to further education after graduation (Morrisroe, 2014, p. 24). Low literacy skills prevent achievement in school which in turn becomes a barrier to success in the workplace. Workers with low literacy levels remain on the margins of society because their impediments to success are foundational and cumulative.

Proficiency in reading is inextricably tied to proficiency in writing. People learn language skills by reading what others write (Krashen, 2004, p. 149). Written works provide models of writing which promote article expression in those who read them. Studies have shown a positive correlation between reading and writing; those with low reading scores do not write as well as more widely read individuals (Broekkamp et al., 2009; Danne, 1991; Eckhoff, 1983). Exposure to written language helps people learn about language structure, which in turn influences their writing (Eckhoff, 1983, p. 607). Only through reading, claims Mary C. Danne, will students "acquire the schema that will enable them to replicate the textures, rhythms, structures, and logic of good writing (1991, p. 188). From writing resumes to writing reports, citizens must rely on writing skills to thrive in the workplace.

The social and economic transformations that the technology revolution has produced continue to affect jobs (OECD, 2013b, p. 23). Occupations that require more highly skilled workers are growing every year, while the demand for less-skilled jobs is shrinking (OECD, 2013a, p. 48). This change in job demand necessitates more literate employees. Furthermore, 
since the demand for jobs that require analysing and communicating information is rising, the demand for highly literate employees is even greater (OECD, 2013b, p. 6).

The accumulated skills of workers are key drivers of economic growth. Canada's C. D. Howe Institute estimates that a 1 percent increase in adult literacy levels generates a 1.5 percent permanent increase in the Gross Domestic Product (GDP), an eventual 2.5 percent rise in national productivity, and a 1.5 percent rise in national income per person (Coulombe et al., 2004, p. 31). According to the OECD, "per capita incomes are higher in countries with larger proportions of adults who reach the highest levels of literacy or numeracy proficiency and with smaller proportions of adults at the lowest levels of proficiency" (2013b, p. 6). Moreover, the effects of increased literacy are three times as great as that for investment in physical capital. (Coulomb et al., 2004, p. 31). Economic growth benefits society as a whole and increases the standard of living for its citizens. To compete in today's competitive world economy, countries

need the majority of their citizens to be proficient in literacy. National Literacy Trust argues that low literacy levels hold back recovery from recessions and financial crises, and even threaten future economic sustainability (Morrisroe, 2014, p. 6).

\section{Reading, Literacy, and Engaged Citizens}

Citizens who are proficient in literacy are not only more successful in the labour force, but also more active and engaged citizens. Both the National Assessment of Adult Literacy and the National Endowment for the Arts in the U.S. report that readers are more likely to vote in elections than non-readers (Kutner et al., p. vi; National Endowment for the Arts, 2007, p. 19). To participate in civic life, citizens must possess the skills to read, analyse, and act upon information. They need to understand their rights, decipher ballots, and comprehend campaign literature (Essential Skills Ontario, 2012). Research has shown that the more literate an 
individual, the more likely he or she is to obtain information on current events, public affairs, and the government — in fact, the type of information needed to make informed political decisions (Kutner et al., p. vi). The OECD has found that, in the 33 countries it surveyed, individuals with low literacy are more likely to believe they have little impact on the political process than those with higher literacy skills (2013b, p. 7).

According to the National Foundation for the Arts, readers are more actively engaged in community and cultural events than non-readers. They are more likely to play sports, visit art museums, and attend plays, musicals, concerts, and sports events (2007, p. 18). Studies of both Canadians and Americans conclude that readers are more likely to volunteer their time and join community groups than non-readers (Hill Strategies Research, 2008, p. 9; National Endowment for the Arts, 2007, pp. 89-90). By doing so, they form stronger bonds with their communities than non-readers (Hill Strategies Research, 2008). People with higher literacy skills have a stronger sense of belonging to their society, are more likely to trust others, are 50 percent more likely to donate to worthy causes, and are 15 percent more likely to do a favour for a neighbour than those with lower literacy skills (Hill Strategies Research, 2008; OECD, 2013b). Reading is positively correlated with social cohesion and integration of individuals into communities; it knits communities together. As Mar and colleagues (2006) have demonstrated, the construct of the reader as isolated "bookworm" is not borne out by the research.

Social and political engagement is a precursor for a fully functioning society. When citizens have strong ties to their communities, they are less likely to suffer from disenfranchisement. Individuals who believe that there is no place for them in society can spiral downwards emotionally, socially, and ethically. Society is a safer, more secure place when citizens have a strong sense of belonging and attachment. 


\section{Reading and Social Justice}

Reading is a tool for social justice and positive change in society. Stories can inspire readers to imagine alternative ways of living, envision improved societies, and fight for important ideals. "In every literate society," writes Alberto Manguel, "learning to read is something of an initiation, a ritualized passage out of a state of dependency and rudimentary communication. The child learning to read is admitted into the communal memory by way of books" (1998, p. 71). The collective wisdom of our ancestors is transmitted through booksbooks that can motivate readers to improve the conditions of their society. Throughout history, stories have acted as an inspiration for readers and an impetus for social change. Research by Mar and colleagues has demonstrated that reading fiction increases empathy, which in turn creates more tolerant, inclusive societies (2009). By imagining what it is like to be another person, readers learn to understand people from different backgrounds, cultures, and races. When they sympathize with fictional characters whose experiences, beliefs, and ideas differ from their own, readers engage in a simulation of real-world encounters. Experiencing empathy towards people outside their social groupings is essential for furthering human rights in societies (Hunt, 2007, p. 39). As Daniel Taylor observes, "Story is our best hope for flying over the chasms that separate individuals, races, genders, ages (and ages), cultures, classes, and the myriad other differences that render us unique" (1996, p. 12).

To fully participate in society as citizens, employees, or consumers, people need to understand and act on textual information. Greater literacy skills reduce barriers to accessing information and services within a society. UNESCO (2015) views literacy as a basic human right: "For individuals, families, and societies alike, it is an instrument of empowerment to improve one's health, one's income, and one's relationship with the world." All citizens- 
including accused persons, witnesses and victims - should have equal access to justice (Essential Skills Ontario, 2012). The justice system can be intricate and complex; individuals with higher literacy skills understand legal processes and their rights within it better than those with lower skills. Rehabilitation services, for example, often involve reading — a significant barrier for those with low literacy skills. Canada's National Reading Campaign (2013) points out that "it is important for society to have a large portion of the population engaged as readers so they can exercise power over their lives and understand how to make effective changes."

Reading is a powerful tool for marginalized groups in society. OECD surveys have found that in most countries, immigrants possess lower literary skills than native-born citizens (2013a, p. $127 ; 2013$ b, p. 11) And in the majority of countries, immigrants do not have the literacy skills required for their jobs (Statistics Canada and OECD, 2011, p. 276). Keren Dali points out that reading can facilitate acculturalization for immigrants. When newcomers arrive in a host country, they need to concentrate on making a living. But work overload as well as language barriers interfere with making social connections. Books compensate for this lack of human contact by functioning as guides and friends. And native-language books can help with the disorientation and culture shock that newcomers experience by providing linguistic and cultural familiarity (Dali, 2012a; Dali, 2012b). Stories about a host nation can also expand newcomers' knowledge of their new country, helping them to understand the national character and mentality of people in an unfamiliar land (Dali, 2013). Reading helps immigrants both adapt to and integrate into a new society.

Marginalized peoples such as aboriginal populations (Statistics Canada and Employment and Social Development Canada, 2013, p. 42), the socio-economically disadvantaged (Morrisroe, 2014, p. 9) and individuals with multiple disabilities (Baer et al., 2009, p. vi) 
generally score lower on literacy tests than non-marginalized peoples. Non-profit organizations such as Toronto's Literature for Life (2015) empower the disenfranchised through reading programs. Literature-for-Life members are young mothers from visible minorities. The reading circles the organization offers take participants out of isolated situations and help them integrate into society. Jo Attila (2014), the Executive Director for the organization, believes that books provide tools for positive self-development and improved self-worth.

Studies show that inmates in correctional facilities score significantly lower on literacy tests than the non-prison population (Morrisroe, 2014, p. 7; Greenberg et al., 2007, p. v). Offenders who improve their literacy skills transition back into society more effectively and are less likely to reoffend than those with low literacy skills (Music, 2012). Changing Lives through Literacy, an American alternative-sentencing program, is based on the belief in the power of literature to transform lives through reading and group discussion (Waxler, 2008). Shakespeare in Shackles, another reading-based program, was created for solitary-confinement inmates in a maximum-security prison. In Shakespeare Saved My Life: Ten Years in Solitary with the Bard, Laura Bates (2013) explains that the program was created to help prisoners successfully re-enter society. Prior to the program, the twenty participants incurred more than 600 write-ups for violent behaviour; during and after the program, just two. Reading Shakespeare, according to one of the participants, provides them with an alternative way of releasing anger and thoughts of revenge (Bates, 2013). By examining the lives of fictional characters, the inmates develop insights into their own motives. Reading about others encourages them to examine their own lives and develop new ways of thinking. By breaking the cycle of violence, such programs make society safer for all citizens.

\section{Role of Libraries}


Libraries can play a critical role in promoting reading. Although initial education is essential in creating a skilled workforce and a fully functioning society, it is only the first step. As people age, their skills diminish. Proficiency in literacy, as the OECD concludes "is closely related to age, reaching a peak at around 30 years of age and declining steadily, with the oldest age groups displaying lower levels of proficiency than the youngest (2013a, p. 24). The National Assessment of Adult Literacy (2005) found that although respondents over 65 represented 15 percent of the NAAL population, they constituted 26 percent of the below-basics category (2005). For skills to remain strong, they need to be continuously developed. The OECD recommends that societies rely less on initial education and more on lifelong, skills-oriented learning to stem the decline in literacy. They also suggest making these opportunities widely available to all citizens (2013b).

No institutions are better situated than libraries to undertake this responsibility. Like lifelong learning, lifelong reading can both stem the natural decline of literacy over time and compensate for low levels of initial education. We know from research by Rodrigo and colleagues (2014) that formal literacy training is not as effective in raising literacy levels as reading for pleasure. Leisure reading also integrates more practically into people's lives than adult education programs (Jensen et al., 2000; Taylor, 2006). Libraries need to promote leisure reading for all customers, including immigrants and the elderly, two of the fastest growing segments of the population in many countries. In addition, books and reading programs for the sociologically disadvantaged and the marginalized would help improve their lives and promote a more inclusive and equitable society. Fostering a culture of books and reading for the young is more important today than in past decades. The National Endowment for the Arts has shown that the 19-24 year-olds read less books than they did in 1982 (2009, p. 4). The OECD's global 
survey of fifteen-year-olds found that 37 percent of students do not read for pleasure at all (2010, p. 12).

Libraries can create a more robust culture of reading by promoting it as a desirable activity. Van Riel, Fowler, and Downes (2008) argue that libraries need to sell the experience of reading, transforming their promotions from a book-centered model (with information about the authors, genres, and awards) to a reader-focused one. Because the question, "What's in it for me?" can be a powerful motivator for readers, librarians need to entice them by appealing to their needs and desires. Librarians who want to create promotional campaigns that will sell the experience of reading will find a myriad of marketing-tool examples in The Reader-friendly Library Service (Van Riel, Fowler, and Downes, 2008).

Increasingly, users enter libraries through virtual, rather than front doors. Scrolling shelves of recommended books and online reviews of books direct readers' attention to a manageable focus for selection. Amazon and Goodreads take this idea one step further by using an algorithm that creates personalized recommendations for their customers, an idea that libraries could investigate.

Libraries should also draw upon the data linking pleasure reading, economic prosperity and social justice in order to make evidence-based decisions. Taking such data to library boards and decision makers can strengthen the mandate for pleasure reading in your institution. If your library does not have a Reader's Advisory department, or if it is poorly staffed and underresourced, using the data to argue for such additions can produce positive results.

Academic libraries, as Dewan (2013) argues, have lagged behind their public library counterparts in stimulating a culture of reading. In-person and online book clubs, author readings and discussion, and one-book-one-community events can entice readers by transforming reading 
from an often unnoticed activity to a participatory event. In a number of academic libraries, "books have become invisible, hidden away in endless rows on multiple floors. Many people enter libraries as browsers, eager to find a book they will enjoy. Faced with overwhelming choice, only our most persevering patrons find the leisure reading material they want" (Dewan 2013, p. 314). Enticing book displays, bookmarks, and booklists help promote a culture of reading and assist readers in finding the book they want. Creating an enjoyable library experience by incorporating in the building such features as cafes, reading rooms with comfortable chairs, and popular reading collections will also help attract readers (Dewan, 2010).

We should never underestimate the power of reading, and especially its power and influence in society. In our globalized world, reading books about other cultures and races can strengthen our understanding of them. We have seen that creating a more literate population has a direct impact on poverty reduction, standard of living, labour productivity, unemployment reduction, political participation, social and cultural engagement, and social justice. Indeed, the well-being of society depends upon the literacy of its citizens. By helping people become more literate, we reduce barriers to a full functioning society. Literacy, as studies have shown, is the lynchpin and cornerstone of a thriving society. Armed with this knowledge, we must promote reading, advocate for readers, and create a strong mandate for books and reading in libraries. We can create the society, and indeed the world, we want to live in by generating a strong culture of reading in our institutions.

\section{References}

Attila, J. (2014). "Diverse reading experiences," Presented at RA in a Day 2014: Transformative: Understanding the Reading Experience, Toronto, Ontario, 7 November, unpublished. 
Baer, J., Kutner, M. Sabatini, J., and White, S. (2009). "Basic reading skills and the literacy of America's least literate adults: Results from the 2003 National Assessment of Adult Literacy (NAAL)", available at: https://nces.ed.gov/pubsearch/pubsinfo.asp?pubid=2009481

Bates, L. (2013). Shakespeare Saved My Life: Ten Years in Solitary with the Bard, Naperville, IL: Sourcebooks.

Broekkamp, H., Janssen, T., and Van Den Bergh, H. (2009). "Is there a relationship between literature reading and creative writing?" The Journal of Creative Behavior, Vol. 43 No. 443, pp. 281-297.

Campbell, A. and Gagnon, N. (2006). "Literacy, life and employment: An analysis of Canadian International Adult Literacy Survey (IALS ) microdata", available at: http://www.conferenceboard.ca/e-library/abstract.aspx?did=1519

Coulombe, S., Tremblay, J., and Marchand, S. (2004). "Literacy scores, human capital and growth across fourteen OECD countries", available at: http://aix1.uottawa.ca/ scoulomb/pages/Coulombe-Tremblay-UOWP0407E.pdf

Daane, M.C. (1991). "Good readers make good writers: A description of four college students”, Journal of Reading, Vol. 35 No. 3, pp. 184-188.

Dali, K. (2012a). "Books in their suitcases: Leisure reading in the lives of Russian-speaking immigrants in Canada", Journal of Librarianship and Information Science, Vol. 45 No. 4, pp. 261-293.

Dali, K. (2012b). "Reading their way through immigration: The leisure reading practices of Russian-speaking immigrants in Canada", Library \& Information Science Research, Vol. 34 No. 3, pp. 197-211. 
Dali, K. (2013). “"Ask me what I read': Readers' advisory and immigrant adaptation”, New Library World, Vol. 114 No. 11-12, pp. 507-526.

Davenport, T.H. (2005). Thinking for a Living: How to Get Better Performance and Results from Knowledge Workers, Boston: Harvard Business School Press.

De Rosa, C., Cantrell, J., Carlsen, M., Gallagher, P., Hawk, J., and Sturtz, C. (2011). "Perceptions of libraries, 2010: Context and community, a report to the OCLC membership", Dublin, OH. available at: http://www.oclc.org/reports/2010perceptions/2010perceptions_all_singlepage.pdf

Dewan, P. (2010). "Why your academic library needs a popular reading collection now more than ever", College \& Undergraduate Libraries, Vol. 17 No. 1, pp. 44-64.

Dewan, P. (2013). "Reading matters in the academic library: Taking the lead from public librarians", Reference \& User Services Quarterly, Vol. 52 No. 4, pp. 309-19.

Eckhoff, B. (1994). “How reading affects children's writing”, Language Arts, Vol. 60 No. 5, pp. $607-616$.

Essential Skills Ontario. (2012). “Literacy and essential skills in Ontario, 2012”, available at: http://www.essentialskillsontario.ca/sites/www.essentialskillsontario.ca/files/Literacy\%20an d\%20Essential\%20Skills\%20in\%200ntario_Final2_0.pdf

Gladwell, M. (2008). Outliers: The Story of Success, London: Allen Lane.

Gold, J. (2002). The Story Species: Our Life-Literature Connection, Toronto, ON: Fitzhenry \& Whiteside.

Gottschall, J. (2012). The Storytelling Animal: How Stories Make Us Human, Boston: Houghton Mifflin Harcourt. 
Greenberg, E., Dunleavy, E., Kutner, M., and White, S. (2007). "Literacy behind bars: Results from the 2003 National Assessment of Adult Literacy Prison Survey", available at: https://nces.ed.gov/pubsearch/pubsinfo.asp?pubid=2007473

Hill Strategies Research. (2008). "Social effects of culture: Exploratory statistical evidence”, available at: http://www.hillstrategies.com/sites/default/files/Social_effects_culture.pdf.

Hoffert, B. (2015). "Materials breakout | materials survey 2015”, Library Journal, available at: http://reviews.libraryjournal.com/2015/03/books/materials-breakout-materials-survey-2015/

Hunt, L. (2007). Inventing Human Rights, New York: Norton.

Jensen, J., Haleman, D., Goldstein, B., and Anderman, E. (1998). "Reasonable choices: Understanding why under-educated individuals choose not to participate in adult education", available at: http://files.eric.ed.gov/fulltext/ED444025.pdf

Krashen, S.D. (2004). Power of Reading: Insights from the Research, Westport, CT: Libraries Unlimited.

Kutner, M., Greenberg, E., Jin, Y., Boyle, B., Hsu, Y., and Dunleavy, E. (2007). "Literacy in everyday life: Results from the 2003 National Assessment of Adult Literacy", available at: https://nces.ed.gov/pubsearch/pubsinfo.asp?pubid=2007480

Literature for Life. (2015). "Literature for life", available at: http://www.literatureforlife.org/ Mance, H., Shubber, K., and Bond, S. (2015). "Book sales rise as readers remain true to type", Financial Times, 10 January.

Manguel. Alberto (1998). A History of Reading, Toronto, ON: Vintage Canada.

Mar, R.A., Oatley, K., Hirsh, J., dela Paz, J., and Peterson, J.B. (2006). “Bookworms versus nerds: Exposure to fiction versus non-fiction, divergent associations with social ability, and 
the simulation of fictional social worlds", Journal of Research in Personality, Vol. 40 No. 5, pp. 694-712.

Mar, R.A., Oatley, K., and Peterson, J.B. (2009). "Exploring the link between reading fiction and empathy: Ruling out individual differences and examining outcomes", Communications, Vol. 34 No. 4, pp. 407-428.

Morrisroe, J. (2014). "Literacy changes lives 2014: A new perspective on health, employment and crime", available at: http://www.literacytrust.org.uk/assets/0002/3684/Literacy_changes_lives_2014.pdf.

Music, E. (2012). "Teaching literacy in order to turn the page on recidivism", Journal of Law \& Education, Vol. 41 No. 4, pp. 723-730.

National Assessment of Adult Literacy. (2005). "A first look at the literacy of America's adults in the 21st century", available at: $\underline{\text { http://nces.ed.gov/naal/pdf/2006470.pdf }}$

National Endowment for the Arts. (2007). "To read or not to read: A question of national consequence", available at: http://arts.gov/sites/default/files/ToRead.pdf

National Endowment for the Arts. (2009). "Reading on the rise: A new chapter in American literacy", available at: https://www.arts.gov/sites/default/files/ReadingonRise.pdf

National Reading Campaign. (2013). "Reading: The facts", available at: http://www.nationalreadingcampaign.ca/research/reading-matters-the-facts/

Oatley, K. (2011). Such Stuff as Dreams: The Psychology of Fiction, Chichester, West Sussex, UK: Wiley-Blackwell.

OECD. (2010). "PISA 2009 results: Executive summary", available at: http://www.oecd.org/pisa/pisaproducts/46619703.pdf 
OECD. (2013a). "OECD skills outlook 2013: First results from the survey of adult skills", available at: http://skills.oecd.org/OECD_Skills_Outlook_2013.pdf

OECD. (2013b). "Skilled for life? Key findings from the survey of adult skills", available at: http://skills.oecd.org/documents/SkillsOutlook_2013_KeyFindings.pdf

OECD and Statistics Canada. (2000). "Literacy in the information age: Final report of the international adult literacy survey", available at: http://www.oecd.org/edu/skills-beyond$\underline{\text { school/41529765.pdf }}$

Rodrigo, V., Greenberg, D., and Segal, D. (2014). "Changes in reading habits by low literate adults through extensive reading", Reading in a Foreign Language, Vol. 26 No. 1, pp. 7391, available at: http://nflrc.hawaii.edu/rfl/April2014/articles/rodrigo.pdf

Ross, C.S. (2000). "Finding without seeking: What readers say about the role of pleasure reading as a source of information", Australasian Public Libraries and Information Services, Vol. 13 No. 2, pp. 72-80.

Ross, C.S., McKechnie, L. (E.F.), and Rothbauer, P. (2006). Reading Matters: What the Research Reveals about Reading, Libraries, and Community, Westport, CT: Libraries Unlimited.

Ross, C. S. (2009). "Reader on top: Public libraries, pleasure reading, and models of reading", Library Trends, Vol. 57 No. 4, pp. 632-656.

Statistics Canada and Employment and Social Development Canada. (2013). "Skills in Canada: First results from the Programme for the International Assessment of Adult Competencies (PIAAC)", available at: http://library.copian.ca/item/12126

Statistics Canada and OECD. (2011). "Literacy for life: Further results from the adult literacy and life skills survey", available at: http://www.statcan.gc.ca/pub/89-555-x/89-555x2013001-eng.htm 
Taylor, D. (1996). The Healing Power of Stories: Creating Yourself through the Stories of Your Life, New York: Doubleday.

Taylor, M.C. (2006). "Informal adult learning and everyday literacy practices”, Journal of Adolescent \& Adult Literacy, Vol. 49 No. 6, pp. 500-509.

Thorton-Verma, H. and Schwartz, M. (2014). “The state of readers' advisory", Library Journal, available at: http://lj.libraryjournal.com/2014/02/library-services/the-state-of-readersadvisory/\#_

UNESCO. (2015). "Literacy”, available at:

http://www.unesco.org/new/en/education/themes/education-building-blocks/literacy/

Van Riel, R., Fowler, O., and Downes, A. (2008). The Reader-friendly Library Service, Newcastle upon Tyne, UK: Society of Chief Librarians.

Waxler, R.P. (2008). “Changing lives through literature”, PMLA, Vol. 123, No. 3, pp.678-682.

Wolf, M. and Barzillai, M. (2009). “The importance of deep reading”, Educational Leadership, Vol. 66 No. 6, pp. 33-37. 